\title{
ASSESSMENT OF HEAVY METAL CONTAMINATION AT WEST AND EAST COASTAL AREA OF PENINSULAR MALAYSIA
}

\author{
Ghufran Redzwan*, Hafizah Abdul Halim, Siti Aisah Alias and M. Motior Rahman \\ ${ }^{1}$ Institute of Biological Sciences - Faculty of Science, Universiti Malaya, 50603 Kuala Lumpur \\ Malaysia \\ * Corresponding author: ghufran@um.edu.my
}

\begin{abstract}
Five heavy metal elements [Pb (II), Cr (VI), Ni (II), Zn (II) and Cu (II)] in the sediment of the two coastal areas had been analyzed of the Mideast and Midwest of Peninsular Malaysia in the year of 2012. This is to assess and monitor contamination of heavy metal at a mangrove area in the state of Negeri Sembilan, Melaka and Pahang. Overall and individual analyses of the heavy metals showed the concentration of the named heavy metals were not at alarming stage. All analyzed elements were found to be much lower than the international guideline provided by the Chinese (EPA-China), Canadian (CEPA) and American (US-EPA). Quantitative assessment using Enrichment Factor shows that all analyses elements were to found be within the degree of background concentration.
\end{abstract}

Keywords: Enrichment factor, Port Dickson, Kuantan, South China Sea, Strait of Malacca, Mangrove Forest Area

Abstrak Lima elemen logam berat [Pb(II), $\mathrm{Cr}(\mathrm{VI}), \mathrm{Ni}(\mathrm{II}), \mathrm{Zn}(\mathrm{II})$ dan $\mathrm{Cu}(\mathrm{II})]$ dalam sedimen kawasan persisiran pantai di pertengahan pantai timur dan barat telah dianalisis pada tahun 2012. Ia nya bertujuan untuk menilai dan memantau kontaminasi logam berat di kawasan bakau di Negeri Sembilan, Melaka dan Pahang. Analisis individu dan keseluruhan bagi logam berat menunjukkan aras kepekatan logam berat yang dinamakan adalah tidak membimbangkan. Kesemua analisis elemen didapati adalah jauh lebih rendah daripada garispanduan yang dikeluarkan oleh negara China, Kanada dan Amerika Syarikat. Penilaian kuantitatif dengan menggunakan Enrichment Factor menunjukkan elemen yang dianalisis berada pada paras kepekatan semulajadi.

Katakunci: Enrichment factor, Port Dickson, Kuantan, Laut China Selatan, Selat Melaka, Kawasan Hutan Bakau

\section{INTRODUCTION}

Peninsular Malaysia is surrounded by the Strait of Malacca as part of the Andaman Sea for the west coast area, and South China Sea for the east coast area. The shoreline for Peninsular Malaysia comprised of $1972 \mathrm{~km}$, while for Sabah and Sarawak, the shoreline is at $1802 \mathrm{~km}$, and 1035 , respectively (Midun, 1988). Degradation of coastal area with reference to its stability and also environmental quality are continuously monitored. Several causes of coastal destruction have been listed to be the coastal erosion, ill-planned development, land reclamation, uncontrolled marine sand mining, environmental degradation, and coastal resources utilisation (Seang \& Latif, 2002). Despite of effort for constant monitoring by the authority, contamination of coastal area in Malaysia is yet to be controlled nor completely reported. Numbers of stakeholders in the western coastal area are more than what we (Malaysian) have for the east coast of Peninsular Malaysia. The three states, Malaysia, Singapore and Indonesia have formed the Malacca Strait Council, and joint-forces with Japan and Korea since 1968 to provide the navigational safety together with remedies against pollution in the strait (Goh \& Cleary, 2005). While in South China Sea, it sees more dispute rather than collaborative work in the area (Schofield \& Storey, 2011). It is hoped that by alarming the stakeholders on the environmental degradation of coastal shall bestow better geopolitical stability in the region. Coastal degradation should be taken as one of the threats. United Nations Conference on Environment and Development (UNCED) in Rio De Janeiro when this subject has been conferred, has recommended that the Integrated Coastal Zone Management (ICZM) be implemented in order to minimize conflicts and to provide for optimal sustainable resource use (Seang \& Latif, 2002). 
This study was carried out to report the degree of contamination for both coastal areas with the heavy metals. Selected areas are to be consisted of mangrove plants which could entrap most of the pollutants either point-source nor non-point source of sediment. Most studies were being carried out at heavily industrialized area such as Port Klang (Tavakoly et al., 2013), Pulau Pinang (Minhat, et al., 2013). Study of heavy metal in the sediment has been carried out throughout the world targeting areas with high anthropogenic activities such as in India (Rokade, 2009), China (Shuai-Long et al., 2013), Magadascar (Hervé et al., 2010), Indonesia (Takarina et al., 2004), Italy (Bertolotto et al., 2005) and several other parts of the world. Interestingly, a study for the sediment of Strait of Malacca also had been conducted as well (Saion et al., 2007). The presence of heavy metals in the coastal sediment indicates contamination by ex situ pollutant or also the alteration of natural geochemical cycles of the monitored metals (Galloway, 1972). Selected areas are to represent both coastal areas of Peninsular Malaysia for the presence of heavy metals in their sediment. Hypothetically, the contamination source could be originated from the river flow passing through industrial areas along the west coast of Peninsular, and also the exploration and refinery of crude oil, and industrial activity on the east coast.

\section{AIM AND OBJECTIVES}

This study is aimed to report the quantitative assessment heavy metal concentration in both of costal area for Peninsular Malaysia due to the unnatural geochemical cycle, which could refer to either anthropogenic or natural disaster, i.e. earthquake or tsunami. It is usual that what is not measured will not be monitored. This is when the possibility of the certain environmental pollution would go unnoticed in time because such pollutant was not measured at the beginning, therefore it is improbable that such parameters to be monitored throughout the time. In this study, selective elements were used to represent heavy metals as part of environmental pollution monitoring program for the coastal area.

\section{MATERIALS AND METHODS}

This study involved a series of field visits, collecting sediment samples for the analysis of heavy metal composition. The analysis was carried out at the University of Malaya laboratory.

\section{Sampling Location}

Five mangrove forest areas were selected from Midwest coast and the Mideast coast of Peninsular Malaysia as for sampling location. Sediment sampling was done since February 2012 until October 2012 during the low tide Figure 1 shows the location of sampling sites for both west and east coast of Peninsular Malaysia for the assessment of heavy metal contamination. Repetition of sampling would be carried out when the initial analysis has indicated heavy metal pollution would have taken place. Meanwhile Table 1 shows the latitude and longitude of sampling sites.

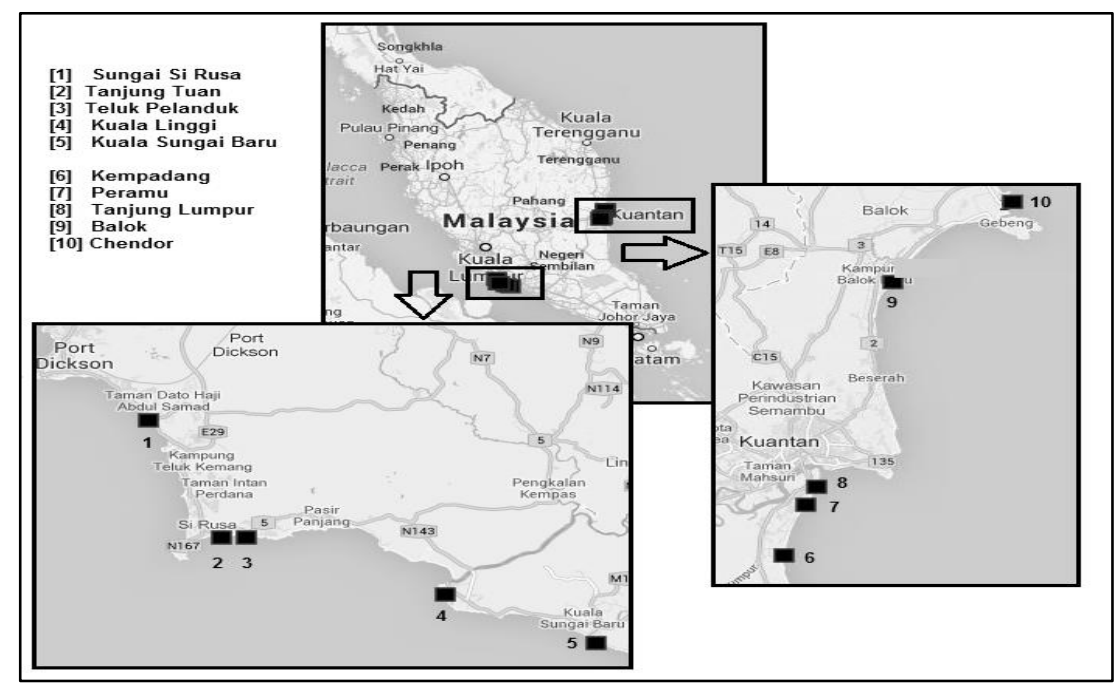

Figure 1. Sampling Sites for West and East Coast of Peninsular Malaysia 
In Midwest coast area, the study was conducted in the coastal with mangrove forest of Negeri Sembilan and Malacca. Sampling sites spread from $\mathrm{N} 2.3^{\circ}, \mathrm{E} 102.0^{\circ}$ to $\mathrm{N} 2.5^{\circ}$, E101.8 ${ }^{\circ}$. Manufacturing, tourism, agricultural and construction sector are among important sectors in Negeri Sembilan which contribute half of the state's gross domestic product (DOS, 2013). While, Malacca state is located in the southern region of Peninsular Malaysia and bordered Negeri Sembilan to the north and State of
Johor to the south. All sites face Straits of Malacca which are sheltered by Sumatera Island. Mangrove forest in south west coast usually can be found on river banks and estuaries. Selected mangrove site in west coast was surrounded heavily with many anthropogenic activities such as construction site in Teluk Pelanduk, fishing and boating activities in $\mathrm{Sg}$. Si Rusa and Linggi, near to recreation and resort activities in Tanjung Tuan and near to power and other industrial processing plants in Kuala Sg. Baru.

Table 1. Latitude and Longitude of Sampling Sites [1-10] for the Assessment of Heavy Metal Contamination in the Sediment

\begin{tabular}{llll}
\hline Location & State & Latitude (North) & Longitude (East) \\
\hline [1] Sungai Si Rusa & Negeri Sembilan & $2^{\circ} 29^{\prime} 51.40^{\prime}$ & $101^{\circ} 50^{\prime} 23.38^{\prime}$ \\
\hline [2] Tanjung Tuan & Negeri Sembilan & $2^{\circ} 25^{\prime} 8.16^{\prime \prime}$ & $101^{\circ} 52^{\prime} 30.34^{\prime \prime}$ \\
\hline [3] Teluk Pelanduk & Negeri Sembilan & $2^{\circ} 25^{\prime} 9.55^{\prime}$ & $101^{\circ} 52^{\prime} 59.42^{\prime}$ \\
\hline [4] Kuala Linggi & Negeri Sembilan & $2^{\circ} 22^{\prime} 54.33^{\prime \prime}$ & $101^{\circ} 58^{\prime} 14.59^{\prime \prime}$ \\
\hline [5] Kuala Sungai Baru & Melaka & $2^{\circ} 21^{\prime} 1.03^{\prime \prime}$ & $101^{\circ} 02^{\prime} 15.30^{\prime \prime}$ \\
\hline [6] Kempadang & Pahang & $3^{\circ} 45^{\prime} 5.89^{\prime \prime}$ & $103^{\circ} 19^{\prime} 32.16^{\prime \prime}$ \\
\hline [7] Peramu & $3^{\circ} 47^{\prime} 4.67$ & $103^{\circ} 20^{\prime} 8.16^{\prime \prime}$ \\
\hline [8] Tanjung Lumpur & Pahang & $3^{\circ} 47^{\prime} 47.61^{\prime \prime}$ & $103^{\circ} 20^{\prime} 24.69^{\prime \prime}$ \\
\hline [9] Pantai Balok & Pahang & $3^{\circ} 55^{\prime} 46.53^{\prime}$ & $103^{\circ} 22^{\prime} 26.59^{\prime \prime}$ \\
\hline [10] Chendor & Pahang & $4^{\circ} 03^{\prime} 46.27^{\prime \prime}$ & $103^{\circ} 23^{\prime} 37.46^{\prime \prime}$ \\
\hline
\end{tabular}

In Mideast coastal area, a study was conducted in the State of Pahang. Sampling sites spread from N $2.7^{\circ}$, E $101.9^{\circ}$ to $\mathrm{N} 4.1^{\circ}$, E $103.3^{\circ}$. Pahang is the largest state in Peninsular Malaysia with the mangrove area located mostly in three districts which is Kuantan, Rompin and Pekan (DOS, 2013). These sites are also located in anthropogenic activity area such as recreational centers, fishing, market and boating activities such as in Kempadang, Tg. Lumpur and Pantai Balok, as well as conversion of land into dumping site of daily waste by the villagers in Chendor and Peramu area. There is also fresh food processing factory located adjacent to Peramu mangrove area with the industrial waste discharge directly into the mangrove area. Adding up to the anthropogenic activity, there is also on-going oil and gas activities at an eastern block of Pahang (Danny, 2009).

\section{Sampling and Heavy Metal Analysis Techniques}

Triplicates sample of soil from the top surface sediment with the depth of $1-10 \mathrm{~cm}$ were taken at each sampling site. All samples were collected with shovel and kept in a sterile Falcon tube. Samples were conserved in cooler box for further analysis in the laboratory. Then, the samples were dried in the oven at $80^{\circ} \mathrm{C}$ for two days. Dried samples were crushed using a Fritish crusher machine to get fine sediment and transferred to the Wykeham Farrace siever machine to separate the sediment size. The sediment with equal or less than 63 mirometer size was collected for acid digestion method using $65 \%$ HNO3: $37 \%$ HCI in a ratio of $4: 2$ on the hot plate until clear fume evolved. Sediment $\leq 63$ micrometer was chosen because fine sediment with that size can restrain more than total sediment (Fortsner \& Solomons, 1980).

The solution was cooled at room temperature for 10min and filtered using Whatman No.1 Qualitative filter paper. Each filtrate was diluted with distilled water up to $50 \mathrm{ml}$ in a $250 \mathrm{ml}$ Erlenmeyer flask. Concentration of five elements: [Pb(II), $\mathrm{Cr}(\mathrm{VI})$, $\mathrm{Cu}(\mathrm{II}), \mathrm{Zn}$ (II) and $\mathrm{Ni}(\mathrm{II})]$ were analysed to represent heavy metals contamination with the use of Atomic Absorption Spectrophotometer (AAS) instrument. 


\section{RESULTS AND DISCUSSION}

As mentioned earlier, five heavy metal elements were used to report the contamination assessment of the selected mangrove areas for both coastal lines. Presence of $\mathrm{Cu}$ (II), $\mathrm{Zn}$ (II), Cd (II) and $\mathrm{Pb}$ (II) show that the alteration of natural geochemical cycle (Galloway, 1972). The mangrove forest area is selected to be the sampling sites as they are to be strategic locations that link marine and terrestrial ecosystem made them suitable station for the settlement and accumulation of heavy metal from the surrounding area for long periods.

Previous studies also supported the circumstance because mangrove surface sediment possesses variable physical and chemical properties such as the sediment particles size and type which consist of sand, clay or silt as well as its ability to become anaerobic and reduced with high sulphide and organic matter content thus it can hold and retain water-borne heavy metal which are introduced into coastal area by river discharge from lithogenic and anthropogenic sources or surface run-off (Pekey, 2006; Praveena et al., 2008; Tam \& Wong, 2000). The dynamic and distribution of heavy metal concentration in mangrove sediment usually affected by few mechanisms such as biological uptake, adsorption, mineralogical compound, hydrodynamic transport and mostly by the industrial discharge, effluent and shipping activities (Gopinath et al. 2010; Hart, 1982; Nobi et al., Sivakumar, \& Kannan, 2010 ). Nevertheless, result and discussion in this study would engage on the concentration of heavy metals presence at the sampling area.

\section{Heavy Metal Analysis}

It is important to investigate heavy metal concentration and distribution in the environment because most heavy metals such as $\mathrm{Pb}$ (II), $\mathrm{Cu}$ (II), $\mathrm{Zn}(\mathrm{II}), \mathrm{As}(\mathrm{V})$ are toxic and not biodegradable in nature thus it will affect human and ecosystem. Table 2 shows the mean concentration of selected elements at each sampling location. All individual elements was totalled up and averaged to represent findings of heavy metal contamination study at the west coast of Peninsular Malaysia. Meanwhile Table 3 shows the same representation of heavy metal study for the east coast of Peninsular Malaysia. Both tables show that the overall heavy metal composition in the sediment of the mangrove area at both coastal do not show the mathematical differences with the average of 0.5 and $0.6 \mathrm{ppm}$ for west coast and east coast, respectively.

Table 2. Mean Concentration of Heavy Metal in Mangrove Surface Sediment of West Coast of Peninsular Malaysia (ppm)

\begin{tabular}{|c|c|c|c|c|c|c|}
\hline Elements & $\begin{array}{c}\text { Sungai Si } \\
\text { Rusa }\end{array}$ & $\begin{array}{c}\text { Tanjung } \\
\text { Tuan }\end{array}$ & $\begin{array}{c}\text { Teluk } \\
\text { Pelanduk }\end{array}$ & $\begin{array}{c}\text { Kuala } \\
\text { Linggi }\end{array}$ & $\begin{array}{c}\text { Kuala Sungai } \\
\text { Baru }\end{array}$ & Average \\
\hline $\mathrm{Pb}(\mathrm{II})$ & 1.200 & 0.161 & 0.525 & 0.416 & 0.547 & 0.560 \\
\hline $\mathrm{Cr}(\mathrm{VI})$ & 0.927 & 0.020 & 3.500 & 0.551 & 1.500 & 1.300 \\
\hline $\mathrm{Cu}(\mathrm{II})$ & 0.082 & 0.131 & 0.219 & 0.296 & 0.154 & 0.176 \\
\hline $\mathrm{Zn}(\mathrm{II})$ & 0.235 & 0.329 & 0.354 & 0.598 & 0.346 & 0.372 \\
\hline $\mathrm{Ni}(\mathrm{II})]$ & 0.127 & 0.077 & 0.500 & 0.112 & 0.230 & 0.209 \\
\hline Total & 2.571 & 0.718 & 5.098 & 1.973 & 2.777 & \\
\hline Average & 0.514 & 0.144 & 1.020 & 0.395 & 0.555 & 0.525 \\
\hline
\end{tabular}


Table 3. Mean Concentration of Heavy Metal in Mangrove Surface Sediment of East Coast of Peninsular Malaysia (ppm)

\begin{tabular}{|c|c|c|c|c|c|c|}
\hline Elements & Kempadang & Peramu & $\begin{array}{c}\text { Tanjung } \\
\text { Lumpur }\end{array}$ & $\begin{array}{c}\text { Pantai } \\
\text { Balok }\end{array}$ & Chendor & Average \\
\hline $\mathrm{Pb}(\mathrm{II})$ & 0.198 & 0.382 & 0.350 & 0.210 & 0.326 & $\mathbf{0 . 2 9 3}$ \\
\hline $\mathrm{Cr}(\mathrm{VI})$ & 0.707 & 0.829 & 1.100 & 0.586 & 0.238 & $\mathbf{0 . 6 9 2}$ \\
\hline $\mathrm{Cu}$ (II) & 0.226 & 1.4 & 0.601 & 1.200 & 0.299 & $\mathbf{0 . 7 4 5}$ \\
\hline $\mathrm{Zn}$ (II) & 0.870 & 1.2 & 1.100 & 0.735 & 1.390 & $\mathbf{1 . 0 5 9}$ \\
\hline $\mathrm{Ni}(\mathrm{II})$ & 0.442 & 0.450 & 0.546 & 0.378 & 0.185 & $\mathbf{0 . 4 0 0}$ \\
\hline Total & $\mathbf{2 . 4 4 3}$ & $\mathbf{4 . 2 6 1}$ & $\mathbf{3 . 6 9 7}$ & $\mathbf{3 . 1 0 9}$ & $\mathbf{2 . 4 3 8}$ & \\
\hline Average & $\mathbf{0 . 4 8 9}$ & $\mathbf{0 . 8 5 2}$ & $\mathbf{0 . 7 3 9}$ & $\mathbf{0 . 6 2 2}$ & $\mathbf{0 . 4 8 8}$ & $\mathbf{0 . 6 3 8}$ \\
\hline
\end{tabular}

Mangrove area at west coast, Teluk Pelanduk has the highest concentration of heavy metals while for the east coast area, Peramu has the highest concentration. The order of heavy metal concentration for west coast is as follow, Teluk Pelanduk > Kuala Sungai Baru > Sungai Si Rusa > Kuala Linggi $>$ Tanjung Tuan ranging from 0.2 to $1.3 \mathrm{ppm}$ while for east coast, Peramu > Tanjung Lumpur > Pantai Balok > Kempadang > Chendor ranging from $0.3-1.1 \mathrm{ppm}$.

Overall analysis shows that the total analysed heavy metals in the sediment of both coastal did not exceed $5 \mathrm{ppm}$. These values are not alarming as they are below guidelines level. China has set the highest value for individual element of $\mathrm{Zn}$ to be at $150 \mathrm{ppm}$ and the rest of other heavy metal elements are below than it (Shuai-Long et al., 2013). While Garbarino et al. (1995) wrote that any heavy metal elements which have the concentration of more than $50 \mathrm{ppm}$ in the sediment to be designated as a polluted area. These two guidelines values are used to support that the presence of heavy metal in both coastal of Peninsular Malaysia is not alarming despite of anthropogenic activity at all sampling areas.

\section{Detailed Heavy Metals Analysis}

Detailed illustration of analysed heavy metal concentration according to each breakdown of elements used for both east and west coast of
Peninsular Malaysia are shown in Figure 2. The breakdown of individual heavy metal elementary study showed inconsistent pattern of its presence. In general, it could be said that $\mathrm{Zn}$ (II) and $\mathrm{Cr}$ (VI) is the prevalent element that can be found in sediment for the mangrove of mid-east coast mid-west coast (exception for Tanjung Tuan), respectively.

Table 4 compares the element in heavy metal analysis in this study to the report by Tavakoly et al. (2013) and Saion et al. (2007) whom included the heavy metal element stated in several guidelines. Report by Xiaoyu et al. (2012) is also used for comparison with the guideline values given by the China Authority. The comparative mean of concentration between values obtained in this study, shows the contamination at the selected coastal area are not as bad as at Port Klang (Tavakoly et al.., 2013). Comparison with the larger area of Strait of Malacca for its sediment sampling (Saion et al., 2007), shows the contamination at the coastal area is relatively lower. Information about heavy metal contamination at South East China Sea is yet to be obtained. Study by Tam and Wong (2000) showed that the heavy metal concentration in study were to be very much lower. They had found that three mangrove swamps in Deep Bay region which were seriously contaminated, with heavy metal concentrations in sediments around $80 \mathrm{ppm} \mathrm{Cu}$, $240 \mathrm{ppm} \mathrm{Zn}, 40 \mathrm{ppm} \mathrm{Cr}, 30 \mathrm{ppm} \mathrm{Ni}, 3 \mathrm{ppm} \mathrm{Cd}$ and $80 \mathrm{ppm} \mathrm{Pb}$. 


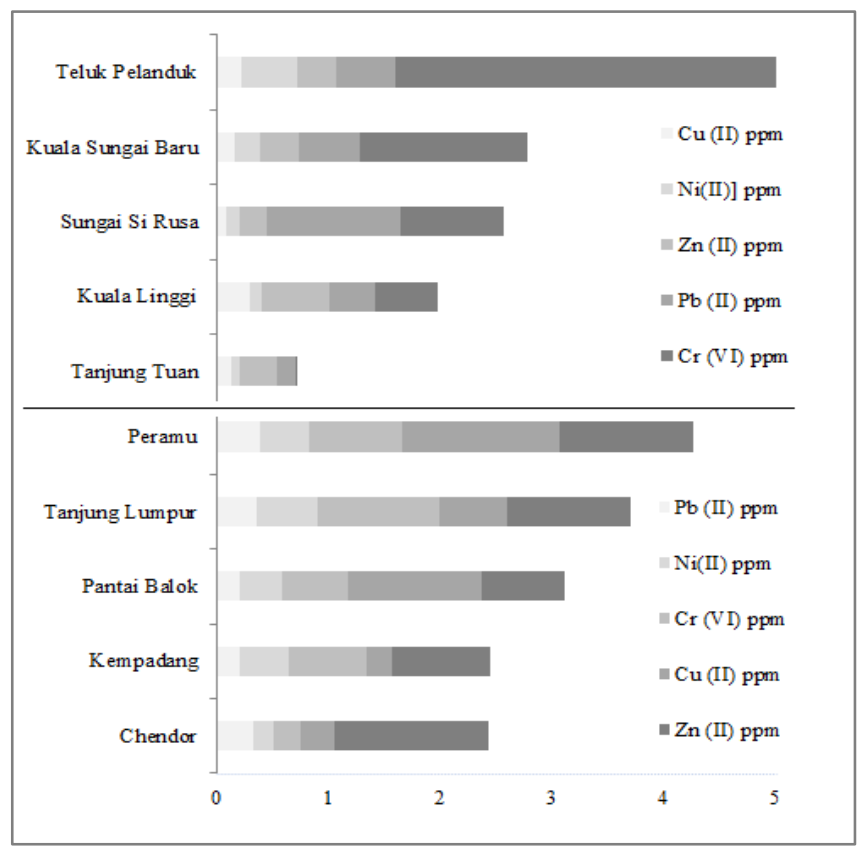

Figure 2. Concentration Analysed Heavy Metals at Selection Locations of West and East Coastal Area of Peninsular Malaysia.

Table 4. Comparison of the Mean for Heavy Metal Concentration in the Sediment of East Coast and West Coast of Peninsular Malaysia with the Sediment of Strait of Malacca and International Guidelines

\begin{tabular}{|c|c|c|c|c|c|c|c|c|}
\hline Element & $\begin{array}{c}\text { East } \\
\text { Coast }\end{array}$ & $\begin{array}{c}\text { West } \\
\text { Coast }\end{array}$ & PK * & $\begin{array}{c}\text { SoM } \\
* *\end{array}$ & $\begin{array}{c}\text { CAN GL } \\
* *\end{array}$ & $\begin{array}{c}\text { ND GL } \\
* *\end{array}$ & $\begin{array}{c}\text { USA-NYS } \\
\text { GL** }\end{array}$ & $\begin{array}{c}\text { CHI } \\
\text { GL }\end{array}$ \\
\hline $\mathrm{Pb}(\mathrm{II})$ & $\begin{array}{c}\mathbf{0 . 2 9 3} \\
\pm 0.084\end{array}$ & $\begin{array}{c}\mathbf{0 . 5 6 0} \\
\pm 0.364\end{array}$ & 128 & 18.43 & 30.20 & 85 & 31 & 60 \\
\hline $\mathrm{Cr}(\mathrm{VI})$ & $\begin{array}{c}\mathbf{0 . 6 9 2} \\
\pm 0.317\end{array}$ & $\begin{array}{c}\mathbf{1 . 3 0 0} \pm 1.343 \\
\pm\end{array}$ & 388 & 39.10 & 52.30 & $(-)$ & 26 & $(-)$ \\
\hline $\mathrm{Cu}(\mathrm{II})$ & $\begin{array}{c}\mathbf{0 . 7 4 5} \\
\pm 0.530\end{array}$ & $\begin{array}{c}\mathbf{0 . 1 7 6} \\
\pm 0.083\end{array}$ & 118 & 17.46 & 18.70 & 36 & 16 & 35 \\
\hline $\mathrm{Zn}(\mathrm{II})$ & $\begin{array}{c}\mathbf{1 . 0 5 9} \\
\pm 0.261\end{array}$ & $\begin{array}{c}\mathbf{0 . 3 7 2} \\
\pm 0.135\end{array}$ & 492 & 63.68 & 124 & 140 & 120 & 150 \\
\hline $\mathrm{Ni}(\mathrm{II})]$ & $\begin{array}{c}\mathbf{0 . 4 0 0} \\
\pm 0.134\end{array}$ & $\begin{array}{c}\mathbf{0 . 2 0 9} \\
\pm 0.172\end{array}$ & 74 & 24.28 & $(-)$ & $(-)$ & $(-)$ & $(-)$ \\
\hline
\end{tabular}

* $\quad$ PK - Port Klang (Tavakoly et al., 2013)

** SoM-Strait of Malacca; CAN GL - Canadian Guideline; ND GL - Netherland Guideline; USA-NYS GL United State of America New York State Guideline (Saion et al., 2007)

*** CHI GL - China Guideline (Xiaoyu et al., 2012)

(-) Not available

\section{Enrichment Factor for Most Prevalent Heavy Metals}

The usual statistical analysis of the concentration of heavy metals in the collected sediment by the use of the mean and standard deviation were used to describe the presence of heavy metals in the area. Some of the data (high standard deviation values) have indicated that neither ANOVA nor Studenttest can be used to determine the statistical 
differences between and within the coastal areas. For analysis purposes in order to assess the degree of heavy metal contamination, the comparative data can be determined using a few descriptive methods such as Enrichment Factor $\left(E_{f}\right)$, Geoaccumulation Index $\left(I_{g e o}\right)$, Contamination Factor $\left(\mathrm{CF}_{)}\right.$and Pollution Load Index $\left(P_{L i}\right)$. The named descriptions have been widely used in many studies.

$f=\frac{\left[\left(\frac{\text { Metal }}{F e}\right)\right] \text { sample }}{\left[\left(\frac{\text { Metal }}{F e}\right)\right] \text { background value }}$

Eq. 1 lists $E_{f}$, which was introduced by Simex and Helz (1981) and later used to describe the relative abundance of a selected environmental substance in the soil (Tam \& Wong, 2000). It is also used to be compared with the substance in the bedrock (Hernandez et al., 2003) It is also used to compare current metal contamination in background areas. Ferum $(\mathrm{Fe})$ acts as reference element to be used at the normalizer during the assessment. Other reference elements that could be used are Manganese (Mn) and aluminium (Al). $\quad E_{f}$ uses indices classification as the indicator which the value begins from less than zero $(<0)$ to more than forty $(>40)$ as the indication for background concentration to extremely high enrichment. Table 5 lists the complete indices of classification according to $E_{f}$ values. Determination of the $E f$ value of this study would assist the interpretation of abundant heavy metal at the location.

Following the earlier study of heavy metal contamination in Port Klang by Tavakoly et al. (2013), Fe was used as the normalizer in this study, with the reference value of 6.2 as recommended by Rokade (2009). Analysis by $E_{f}$ is shown in Table 6 which concludes that the presence of $\mathrm{Zn}$ (II) and $\mathrm{Cr}$ (VI), the two most prevalent elements in both coastal areas are not alarming. Both elements show that they were within the degree of enrichment of their background concentration. By comparison to similar study by Tavakoly et al. (2013), whom found the $E f$ for $\mathrm{Zn}(\mathrm{II})$ and $\mathrm{Cr}(\mathrm{VI})$ were to be in between $2<\mathrm{EF}<5$, indicating that the sediment of Port Klang Strait had moderate anthropogenic inputs of these heavy metals

Table 5. Classification for Degree of Enrichment according to its Indices (Rokade, 2009)

\begin{tabular}{lc}
\hline EF Indices & Degree of Enrichment \\
\hline $\mathrm{EF} \leq 1$ & Background concentration \\
\hline EF 1-2 & Depletion to minimal enrichment \\
\hline EF 2-5 & Moderate enrichment \\
\hline EF 5-20 & Significant enrichment \\
\hline EF 20-40 & Very high enrichment \\
\hline EF $>$ 40 & Extremely high enrichment \\
\hline
\end{tabular}

Table 6. Analysis of Enrichment Factor for Prevalent Heavy Metal Element in the Mid-East and Mid-West Coast of Peninsular Malaysia

\begin{tabular}{|c|c|c|c|c|c|c|}
\hline Elements & Kempadang & Peramu & $\begin{array}{c}\text { Tanjung } \\
\text { Lumpur }\end{array}$ & $\begin{array}{c}\text { Pantai } \\
\text { Balok }\end{array}$ & Chendor & Average \\
\hline $\mathrm{Zn}(\mathrm{II})$ & 0.870 & 1.2 & 1.100 & 0.735 & 1.390 & 1.059 \\
\hline$E_{f}$ & 0.14 & 0.19 & 0.18 & 0.12 & 0.22 & 0.17 \\
\hline Location & $\begin{array}{c}\text { Sungai Si } \\
\text { Rusa }\end{array}$ & $\begin{array}{c}\text { Tanjung } \\
\text { Tuan }\end{array}$ & $\begin{array}{c}\text { Teluk } \\
\text { Pelanduk }\end{array}$ & $\begin{array}{c}\text { Kuala } \\
\text { Linggi }\end{array}$ & $\begin{array}{c}\text { Kuala Sg. } \\
\text { Baru }\end{array}$ & Average \\
\hline $\mathrm{Cr}(\mathrm{VI})$ & 0.927 & 0.020 & 3.500 & 0.551 & 1.500 & 1.300 \\
\hline$E_{f}$ & 0.15 & 0.00 & 0.56 & 0.09 & 0.24 & 0.21 \\
\hline
\end{tabular}




\section{CONCLUSION}

The average concentration of heavy metal $[\mathrm{Pb}$ (II), $\mathrm{Cr}$ (VI), $\mathrm{Cu}$ (II), Zn (II) and Ni (II)] at the sediment of coastal area for the Mideast and Midwest coast of Peninsular Malaysia in the year of 2012, were not at the alarming stage. Even at the individual analysis of heavy metal, their concentration was found to be very much lower than the international guideline provided by China, Canada and USA. These values are not expected to significantly change at present year of 2014, since there was no major anthropogenic activity has been reported at the sampling location. Detailed analysis using Enrichment factor $\left(E_{f}\right)$ also has supported this deduction. Only the highest concentration of heavy metal, i.e. $\mathrm{Zn}$ in East Coast, and $\mathrm{Cr}$ in West Coast were analyzed using $E f$. The rest of the other four heavy metals index followed the classification given by the analyzed $E_{f}$ were to be less than one, i.e. Group $E_{f}<1$. The other four values, the concentration were to have lower values. In addition, amongst the sampling locations, Peramu (east coast) and Teluk Pelanduk (west coast) were found to have the highest total concentration of heavy metals. Analyses with other indices were not carried since $E_{f}$ alone has been a sufficient heavy metal pollution indicator.

Data collection for the accumulated heavy metals at the mangrove forest is suggested to be used for the pollution monitoring because this area is known to possess multiple physical and chemical properties that can hold and retain heavy metals. Comparative data with other mangrove area such as in Hong Kong have shown the accumulation of heavy metal in such area would be higher when the pollution incidents regularly occur. Therefore, with low concentration of heavy metals together with similar findings of Ef analysis indicated that no excessive heavy metal discharge to the environment in the studied area has taken place. Therefore, with low concentration of heavy metals together with similar findings of $E_{f}$ analysis indicated that no excessive heavy metal discharge to the environment in the studied area has taken place.

\section{ACKNOWLEDGEMENTS}

The authors wish to express a gratitude to the Universiti Malaya Research Grant (UMRG) with project number RG129-12SUS, and Universiti Malaya Postgraduate Research Grant (PV068/2012A).

\section{REFERENCES}

1. Bertolotto, R. M., Tortarolo, B., Frignani, M., Bellucci, L. G., Albanese, S., Cuneo, C., . . . Gollo, E. (2005). Heavy metals in surficial coastal sediments of the Ligurian Sea. Mar. Pollut. Bull., 50(3), 348-356.

2. Danny, Y. ( 2009, 17 February 2009.). Tanjong Agas to develop RM8 bil multipurpose industrial park., The Star, p. 8.

3. DOS, D. o. S. (2013). Gross Domestic Product (GDP) by State, 2010 (Updated: 17/10/2011) Retrieved 6 March, 2013, from http://www.statistics.gov.my/portal /index.php?option=com_content\&id =1300:gross-domestic-product-gdp

4. Fortsner, U., \& Solomons, W. (1980). Assessment of sources and intensities. Environmet Technology Letter, 1, 494-505.

5. Galloway, J. N. (1972). Heavy Metals in Coastal Sediments. Calif. Afar. Res. Comm., CalCOR'I Rept., 16, 112-117.

6. Garbarino, J. R., Hayes, H. C., Roth, D. A., Antweiler, R. C., Brinton, T. I., \& Taylor, H. E. (1995). Heavy Metals in the Mississippi River. Contaminants in the Mississippi River - U.S. GEOLOGICAL SURVEY CIRCULAR. Retrieved from ubs.usgs.gov/circ/circ1133/heavymetals.html website:

7. Goh, K. C., \& Cleary, M. (2005). Environment and Development in the Straits of Malacca (Vol. 10). Singapore: Routledge.

8. Gopinath, A., Kumar, N. C., Jayalakshmy, K. V., Padmalal, D., \& Nair, S. M. (2010). A baseline study of trace metals in a coral reef sedimentary environment, Lakshadweep Archipelago. Environmental Earth Sciences, 59(1245-1266).

9. Hart, B. T. (1982). Uptake of trace metals by sediments and suspended particulates: a review. Hydrobiologia, 9(1), 299-313.

10. Hernandez, L., Probst, A., Probst, J. L., \& Ulrich, E. (2003). Heavy metal distribution 
in some French forest soils; evidence for atmosphere contamination. The Science of Total Environment, 312, 195-210.

11. Hervé, R. P., Andriamalala, R., Yves, M., Marcellin, R., Christine, R., \& Andriamandimbisoa, N. (2010). Assessment of heavy metals concentrations in coastal sediments in north-western cities of Madagascar. African Journal of Environmental Science and Technology 4 (2), 51-60.

12. Midun, Z. (1988). Coastal Erosion: Problems and Solution. . Paper presented at the Proceeding 11 th Annual Seminar of the Malaysian Society of Marine Science.

13. Minhat, F. I., Yahya, K., Talib, A., \& Ahmad, O. (2013). A Survey of Benthic Assemblages of Foraminifera in Tropical Coastal Waters of Pulau Pinang, Malaysia. Tropical Life Science Research, 24(1), 3543.

14. Nobi, E. P., Dilipan, E., Thangaradjou, T., Sivakumar, K., \& Kannan, L. (2010 ). Geochemical and geo-statistical assessment of heavy metal concentration in the sediments of different coastal ecosystems of Andaman Islands, India. Estuarine, Coastal and Shelf Science, 87( 2), 253-264.

15. Pekey, H. (2006). Heavy Metals Pollution Assessment in Sediments of the Izmit Bay, Turkey. . Environmental Monitoring and Assessment, 49, 1051-1063.

16. Praveena, S. M., Ahmed, A., Radojevic, M., Abdullah, M. H., \& Aris, A. Z. (2008). Heavy metals in mangrove surface sediment of Mengkabong Lagoon, Sabah: multivariate and geoaccumulation index approaches. International Journal of Environmental Research 2, 139-148.

17. Rokade, M. A. (2009). Heavy Metal Burden in Coastal Marine Sediments of North West Coast of India in Relation to Pollution. University of Mumbai, Mumbai, India.

18. Saion, E., Wood, A. K. H., Sulaiman, Z.A. ,A,A,Elias,M.S.,\&B.S.W.(2007).
Determination of Heavy Metal Pollution in Depth Profile of Marine Sediment Samples from the Strait of Malacca. Fresenius Environmental Bulletin, 16(10),1279-1287.

19. Schofield, C. H., \& Storey, I. (2011). The South China Sea Dispute: Increasing Stakes and Rising Tensions: Jamestown Foundation.

20. Seang, S. H., \& Latif, Z. A. (2002). Future Management Of Shoreline Area Through Integrated Shoreline Management Plan. 1st Annual Seminar On Sustainability Science And Management: Issues of The Coastal Zone, 1(1), 15.

21. Shuai-Long, W., Xiang-Rong, X., Yu-Xin, S., Jin-Ling, L., \& Hua-Bin, L. (2013). Heavy metal pollution in coastal areas of South China: A review. Marine Pollution Bulletin, 76, 7-15.

22. Simex, S., \& Helz, G. (1981). Regional geochemistry of trace metal elements in Chesapeake Bay sediments. Environmental Geology, 3(6), 315-323.

23. Takarina, N. D., Browne, D. R., \& Risk, M. J. (2004). Speciation of heavy metals in coastal sediments of Semarang, Indonesia. Baseline / Marine Pollution Bulletin, 49, 854-874.

24. Tam, N. F. Y., \& Wong, Y. S. (2000). Spatial variation of heavy metals in surface sediments of Hong Kong mangrove swamps. Journal of Environmental Pollution 110(2), 195-205.

25. Tavakoly, S. B., Salleh, A., Rezay, M., Saadati, N., Narimany, L., \& Tehrani, G. M. (2013). Distribution and Contamination of Heavy Metal in the Coastal Sediments of Port Klang, Selangor, Malaysia. Water, Air, \& Soil Pollution, 224.

26. Xiaoyu, L., Lijuan, L., Yugang,W., Geping, L., Xi, C., Xiaoliang, Y., .Xingyuan, H. (2012). Integrated Assessment of Heavy Metal Contamination in Sediments from a Coastal Industrial Basin, NE China. PLoS One, 7(6). 